\title{
Effect of Annealing Temperature and Ambient on Formation, Composition and Bandgap of $\mathrm{Cu}_{2} \mathrm{ZnSnS}_{4}$ Thin Films
}

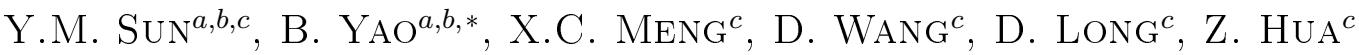 \\ ${ }^{a}$ State Key Lab of Superhard Material and College of Physics, Jilin University, Changchun 130023, P.R. China \\ ${ }^{b}$ Key Laboratory of Physics and Technology for Advanced Batteries of Ministry of Education, \\ College of Physics, Jilin University, Changchun, 130012, China \\ ${ }^{c}$ Key Laboratory of Functional Materials Physics and Chemistry of the Ministry of Education, \\ Jilin Normal University, Siping 136000, P.R. China
}

(Received January 29, 2014; in final form April 18, 2014)

\begin{abstract}
Amorphous $\mathrm{Cu}-\mathrm{Zn}-\mathrm{Sn}-\mathrm{S}$ precursor films were prepared by sol-gel and spin-coating with copper chloride, zinc chloride, tin chloride and thiourea solutions as starting materials. $\mathrm{A} \mathrm{Cu}_{2} \mathrm{ZnSnS}_{4}$ film with kesterite structure and a small amount of chlorine formed when the precursor was annealed under Ar ambient at temperature above $200{ }^{\circ} \mathrm{C}$, but its atomic ratios of $\mathrm{Cu}: \mathrm{Zn}: \mathrm{Sn}: \mathrm{S}$ far deviated from stoichiometric ratios of the $\mathrm{Cu}_{2} \mathrm{ZnSnS}_{4}$. However, when the precursor films were annealed with sulfur powder together at temperatures between 360 and $480{ }^{\circ} \mathrm{C}$, the CZTS film containing a very small amount of $\mathrm{Cl}$ formed, and its atomic ratio change little for $\mathrm{Cu}, \mathrm{Zn}$, and $\mathrm{Sn}$, increases for $\mathrm{S}$ and decreases for $\mathrm{Cl}$ with increasing temperature. When the temperature is $480{ }^{\circ} \mathrm{C}$, a CZTS only has $\mathrm{Cu}, \mathrm{Zn}$, $\mathrm{Sn}$, and $\mathrm{S}$ element is fabricated, and the atomic ratio of $\mathrm{Cu}: \mathrm{Zn}: \mathrm{Sn}: \mathrm{S}$ is near the stoichiometric ratio. The bandgap of the CZTS decreases with increasing annealing temperature. The mechanisms of the formation and the properties of the CZTS are suggested in the present work.
\end{abstract}

DOI: 10.12693 /APhysPolA.126.751

PACS: $68.55 .-\mathrm{a}$

\section{Introduction}

$\mathrm{Cu}_{2} \mathrm{ZnSnS}_{4}$ (CZTS) is one of the most interesting absorbing materials for solar cells, which has a high absorbing coefficient of over $10^{4} \mathrm{~cm}^{-1}$ and an optimal fundamental band gap energy of $1.5 \mathrm{eV}[1-5]$. Its constituent elements are nontoxic and cheap. CZTS based solar cell is expected to have a theoretical efficiency of more than $30 \%$ [6], and has been extensively investigated in recent years [7-12]. Lots of methods for the fabrication of CZTS thin film have been used, such as pulsed laser deposition [13], RF magnetron sputtering [14], coevaporation [15], spray pyrolysis [16], and solution-based synthesis [17]. Sol-gel method is a very simple, low-cost, and a non vacuum deposition technique, which is also used for preparing CZTS thin film [18-22]. The CZTS precursor solution generally consisted of chloride, but little literatures consider chlorine element after heat treatment.

The S loss and compensation during deposition and the annealing is a critical factor to have cells with good performance [23]. The CZTS thin films are most often annealed in $\mathrm{H}_{2} \mathrm{~S}$ or $\mathrm{S}$ atmosphere, but $\mathrm{H}_{2} \mathrm{~S}$ is well known as a toxic gas. Khalkar et al. [24] suggested that the sulfurization in the furnace in sulfur vapor was more reliable than the annealing in sulfurization chamber using $\mathrm{H}_{2} \mathrm{~S}$ gas. In this paper, $\mathrm{Cu}_{2} \mathrm{ZnSnS}_{4}$ thin films are prepared

*corresponding author; e-mail: binyao@jlu.edu.cn by sol-gel followed by annealing under Ar ambient and sulphur atmosphere. The effect of annealing temperature and ambient on formation, composition and bandgap of $\mathrm{Cu}_{2} \mathrm{ZnSnS}_{4}$ thin films is studied.

\section{Experimental procedures}

Copper chloride $(1.9 \mathrm{M})$, zinc chloride $(1.15 \mathrm{M})$, tin chloride $(1 \mathrm{M})$, and thiourea $(8 \mathrm{M})$, respectively, were dissolved in deionized water, ethanol, and polyethyleneglycol as precursor solution. The clear yellow solution was formed when stirred at $45^{\circ} \mathrm{C}$ for $40 \mathrm{~min}$. The sol solution was spin coated on soda lime glass substrates at $2500 \mathrm{rpm}$ for $40 \mathrm{~s}$ to form a film and then the film was annealed at $110^{\circ} \mathrm{C}$ for $10 \mathrm{~min}$ for drying. The coating and drying processes were repeated 3 times. One part of the as-coated films were annealed for $1 \mathrm{~h}$ under $\mathrm{Ar}$ ambient at $120,160,240$, and $310^{\circ} \mathrm{C}$, respectively, and the others were annealed for $1 \mathrm{~h}$ under sulphur (S) atmosphere at $360,400,440$, and $480^{\circ} \mathrm{C}$, respectively in a tubular furnace with two zones (Fig. 1), where one zone was for laying the as-coated thin film, and the other was for laying $\mathrm{S}$ source. The sublimation temperature of the $\mathrm{S}$ source is $446^{\circ} \mathrm{C}$. Both the films and $\mathrm{S}$ source were heated and cooled at the same time.

The thermal analysis was investigated by differential thermal analysis (Thermo plus EVO II TG/DTA) at a heating rate of $10 \mathrm{~K} / \mathrm{min}$. Structural characterizations of samples were examined by X-ray diffraction (XRD, $\mathrm{D} / \max 2500 / \mathrm{PC}, \mathrm{Cu}-K_{\alpha_{1}}, \lambda=1.5406 \AA$ ), scanning electron microscopy (SEM, S-570) and Raman spectroscopy. The Raman spectroscopy measurement was carried out 


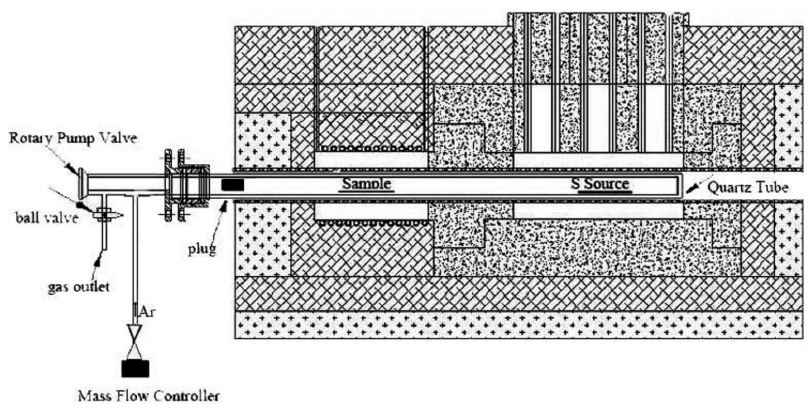

Fig. 1. A schematic of the two-zone tubular furnace.

with Invia Raman spectrometer with excitation wavelength of $514 \mathrm{~nm}$. The crystallite size is calculated by Scherrer formula $D=0.89 \lambda / \beta \cos \theta$ ( $\beta$ is full width at maximum (FWH M), $\theta$ is Bragg angle, $\lambda$ is X-ray wavelength, $D$ is grain size). The composition of the films was detected by energy-dispersive X-ray spectroscopy (EDX). The optical properties of thin films were examined by a UV-visible spectrophotometer (UV-VIS, UV-5800PC).

\section{Results and discussion}

Figure 2 shows the TG and DTA curves of the amorphous $\mathrm{Cu}-\mathrm{Zn}-\mathrm{Sn}-\mathrm{S}$ precursor. The significant weight loss is observed in the TG curve and there are three endothermic peaks in the DTA curve. In order to comprehend the process of thermal decomposition, the as-coated films were annealed at $120,160,240$ and $310^{\circ} \mathrm{C}$ for $1 \mathrm{~h}$ without sulfurization, respectively.

Figure 3 shows XRD patterns of amorphous $\mathrm{Cu}-\mathrm{Zn}-$ Sn-S precursor films annealed under Ar ambient at different temperatures. Only an amorphous-like diffraction is observed in the thin film annealed at $120^{\circ} \mathrm{C}$, indicating that the film has amorphous structure. After annealing at $160^{\circ} \mathrm{C}$, an unidentified phase is observed at near $48^{\circ} \mathrm{C}$, but disappears at high temperatures. The diffraction peaks with diffraction angles of the (112) and (220) planes of CZTS with kesterite structure are observed, indicating that a CZTS with kesterite structure forms at $240^{\circ} \mathrm{C}$. The crystal quality of the CZTS increases at $310^{\circ} \mathrm{C}$. The results are similar to Ref [21].

Figure 4 shows the chemical composition in atomic percent of amorphous $\mathrm{Cu}-\mathrm{Zn}-\mathrm{Sn}-\mathrm{S}$ precursor films annealed at different temperatures under Ar ambient. It is found that the amorphous $\mathrm{Cu}-\mathrm{Zn}-\mathrm{Sn}-\mathrm{S}$ precursor contains a lot of chlorine and its composition ratios do not change until the annealing temperature reaches $160^{\circ} \mathrm{C}$. The composition ratio of chlorine decreases greatly in the temperature ranging from 160 to $310^{\circ} \mathrm{C}$, accompanying by the decrease in chlorine, the composition ratios of copper, zinc and tin all increase slowly.

Based on the results mentioned in Figs. $2-4$, it is deduced that the first slow weight loss in the temperatures of $160-200^{\circ} \mathrm{C}$ shown in the TG curve is due to the evaporation of residual solvent. The second weight steep loss

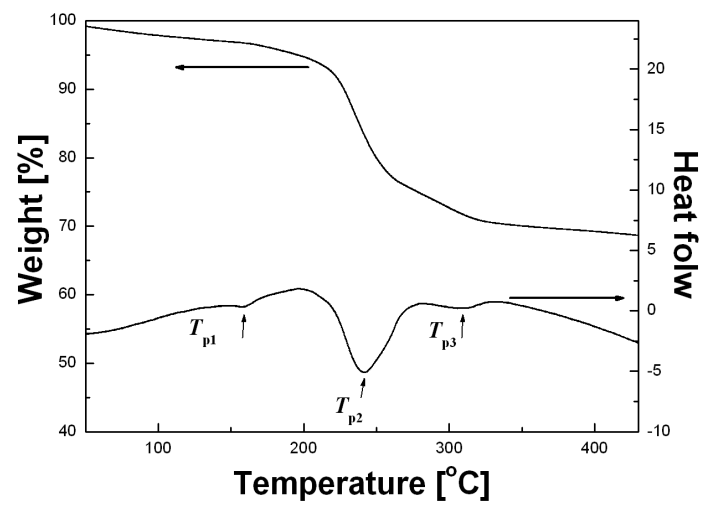

Fig. 2. TG and DTA curves of the amorphous $\mathrm{Cu}-\mathrm{Zn}-$ $\mathrm{Sn}-\mathrm{S}$ precursor.

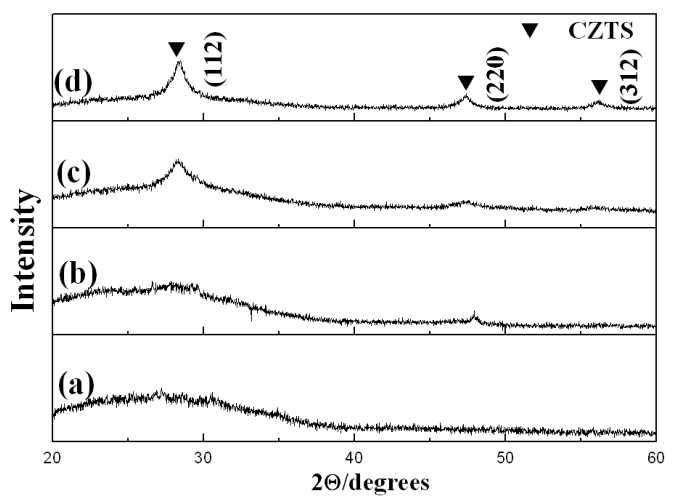

Fig. 3. XRD patterns of amorphous $\mathrm{Cu}-\mathrm{Zn}-\mathrm{Sn}-\mathrm{S}$ precursor films annealed under $\mathrm{Ar}$ ambient at different temperatures of (a) 120 , (b) 160 , (c) 240 , and (d) $310^{\circ} \mathrm{C}$, respectively.

in the temperatures of $200-240^{\circ} \mathrm{C}$ corresponds to the decomposition of thiourea [19] and the chlorides, accompanied by the decomposition, CZTS forms. The third weight loss in TG curve should be due to the evaporation of sulfide and chloride. Chaudhuri et al. [25] think that the first small endothermic peak $T_{p 1}$ in DTA curve may be due to decomposition of excess thiourea near the melting point. The second sharp $T_{p 2}$ corresponds to the formation of CZTS. We cannot be sure what the third $T_{p 3}$ corresponds to, maybe some types of sulfides. Anyway, annealing at $310^{\circ} \mathrm{C}$ without sulfurization treatment, a part of chlorine still exists and the content of sulfur is far less than that of the stoichiometry of CZTS. Therefore, the amorphous $\mathrm{Cu}-\mathrm{Zn}-\mathrm{Sn}-\mathrm{S}$ precursor films need to be annealed at higher temperatures under sulfur atmosphere.

Figure 5 shows the XRD patterns of amorphous $\mathrm{Cu}^{-}$ $\mathrm{Zn}-\mathrm{Sn}-\mathrm{S}$ precursor films annealed at different temperatures of 360 to $480^{\circ} \mathrm{C}$ in the tubular furnace with sulfur powder. After annealing at $360^{\circ} \mathrm{C}$, the diffraction peaks of the (112), (220), and (312) planes of the CZTS with kesterite structure are observed, indicating that the amorphous precursor film crystallizes into crystalline 


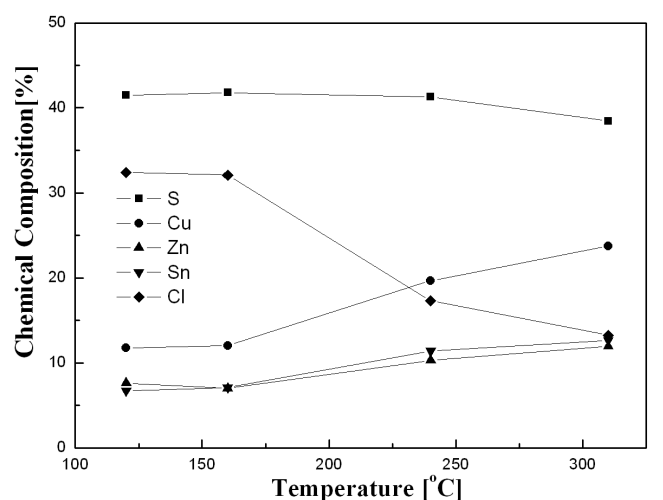

Fig. 4. Chemical composition in atomic percent of amorphous $\mathrm{Cu}-\mathrm{Zn}-\mathrm{Sn}-\mathrm{S}$ precursor films annealed at different temperatures under Ar ambient.

CZTS film with kesterite structure. The intensity of (112) diffraction peak increases and the corresponding FWHM decreases with increasing temperature, indicating that the crystal quality of the CZTS becomes better. The grain size of CZTS phase is calculated by using the Scherrer formula and the FWHM of the (112) diffraction peak. The average grain sizes of the CZTS phase obtained by annealing at $360,400,440$, and $480^{\circ} \mathrm{C}$ are $5.3,5.5,6.6$, and $10.8 \mathrm{~nm}$, respectively, increasing with increasing annealing temperature.

Fig. 6 shows the XRD patterns of the (112) plan corresponding to Fig. 5. The peak position almost has not change with increasing annealing temperature.

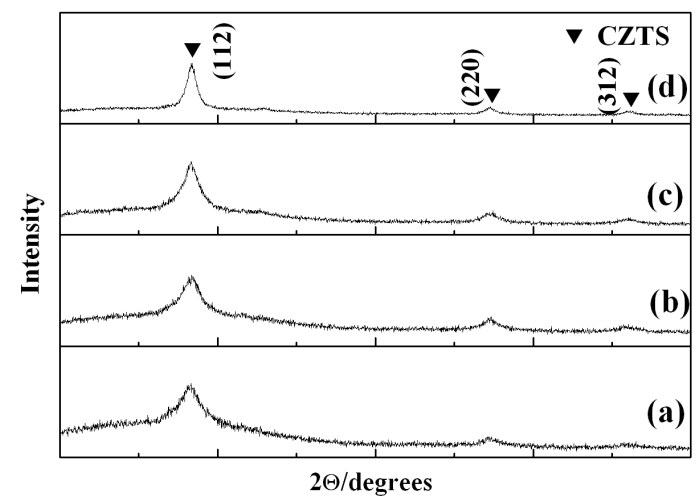

Fig. 5. XRD patterns of CZTS thin films annealed with sulfur powder at different temperatures of (a) 360, (b) 400 , (c) 440 , and (d) $480^{\circ} \mathrm{C}$, respectively.

Figure 7 shows the chemical composition in atomic percent of amorphous $\mathrm{Cu}-\mathrm{Zn}-\mathrm{Sn}-\mathrm{S}$ precursor films annealed at different temperatures with sulfur powder. The ratios of metal elements in $\mathrm{Cu} /(\mathrm{Zn}+\mathrm{Sn})$ and $\mathrm{Zn} / \mathrm{Sn}$ were around 0.90 and 1.27 , showing that thin films are of $\mathrm{Cu}-$ poor and Zn-rich nature. Besides copper, zinc, tin and sulfur, a little of chlorine is also observed in the thin film annealed at $360^{\circ} \mathrm{C}$. The composition ratios change little

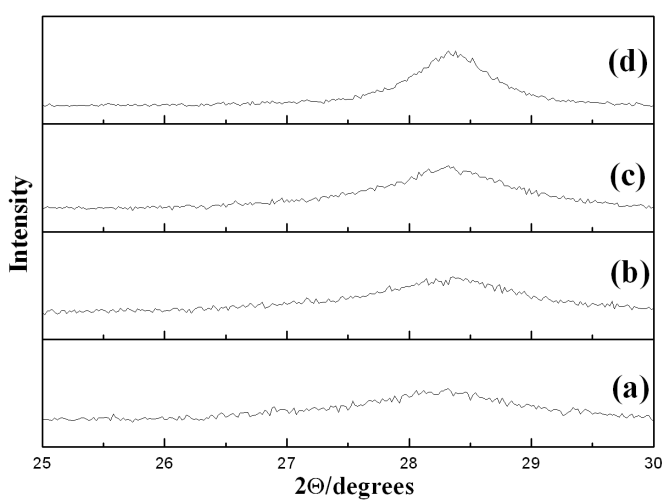

Fig. 6. XRD patterns of (112) peak of the CZTS thin films annealed with sulfur powder at different temperatures of (a) 360 , (b) 400 , (c) 440 , and (d) $480^{\circ} \mathrm{C}$, respectively.

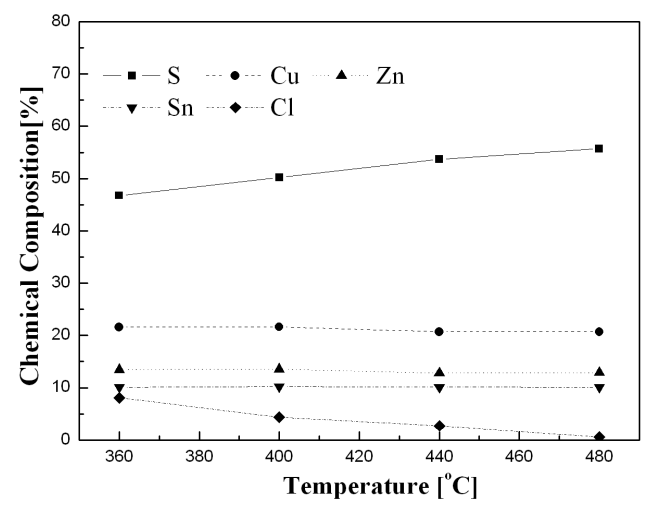

Fig. 7. Chemical composition in atomic percent of amorphous $\mathrm{Cu}-\mathrm{Zn}-\mathrm{Sn}-\mathrm{S}$ precursor films annealed at different temperatures with sulfur powder.

for copper, zinc and tin, decrease for chlorine and increase for sulfur with increasing temperature. When the annealing temperature reaches $480^{\circ} \mathrm{C}$, the chlorine content decreases to $0.55 \%$, implying that the CZTS almost consists of $\mathrm{Cu}, \mathrm{Zn}$, Sn and $\mathrm{S}$.

It is noted from Fig. 7 that the $\mathrm{S}$ content increases from $46.8 \%$ to $55.7 \%$ as the temperature increases from 360 to $480^{\circ} \mathrm{C}$. If the increased $\mathrm{S}$ content is filled in $\mathrm{S}$ vacancy in the CZTS, the lattice constants should increase with increasing $\mathrm{S}$ content. However, combining results of Figs. 6 and 7, the lattice constants almost do not change with increasing $\mathrm{S}$ content. So, the increased $\mathrm{S}$ is not filled in $\mathrm{S}$ vacancy. It is known that ion radius of $\mathrm{Cl}^{-}(0.181 \mathrm{~nm})$ is almost the same as that of $\mathrm{S}^{2-}(0.182 \mathrm{~nm})$, and the $\mathrm{Cl}$ content decreases from $8.08 \%$ to $0.55 \%$, accompanied by the increase in $\mathrm{S}$ content from $46.8 \%$ to $55.7 \%$. If the CZTS contains $\mathrm{Cl}^{-}$in $\mathrm{S}^{2-}$ site, the substitution of $\mathrm{S}^{2-}$ for $\mathrm{Cl}^{-}$would not lead to obvious change of the lattice constants, in agreement with the results of XRD in Figs. 6 and 7. Therefore, we deduce that the chlorine may incorporate into the CZTS thin films and is substituted for the sulfur gradually when the CZTS is annealed under S ambient. 


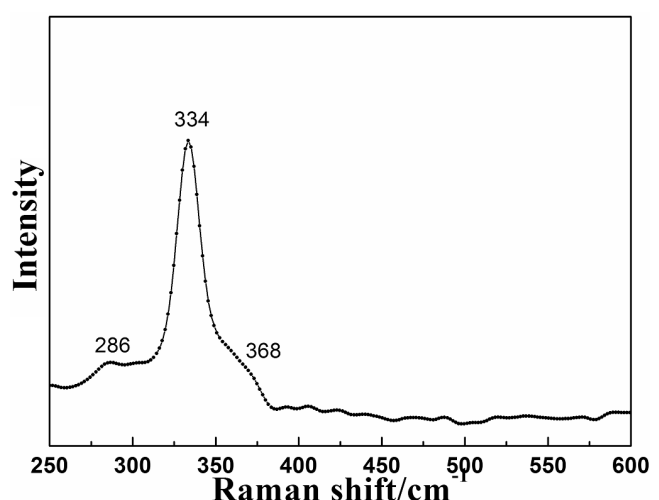

Fig. 8. Raman spectrum of amorphous $\mathrm{Cu}-\mathrm{Zn}-\mathrm{Sn}-\mathrm{S}$ precursor film annealed at $480{ }^{\circ} \mathrm{C}$ with sulfur powder.

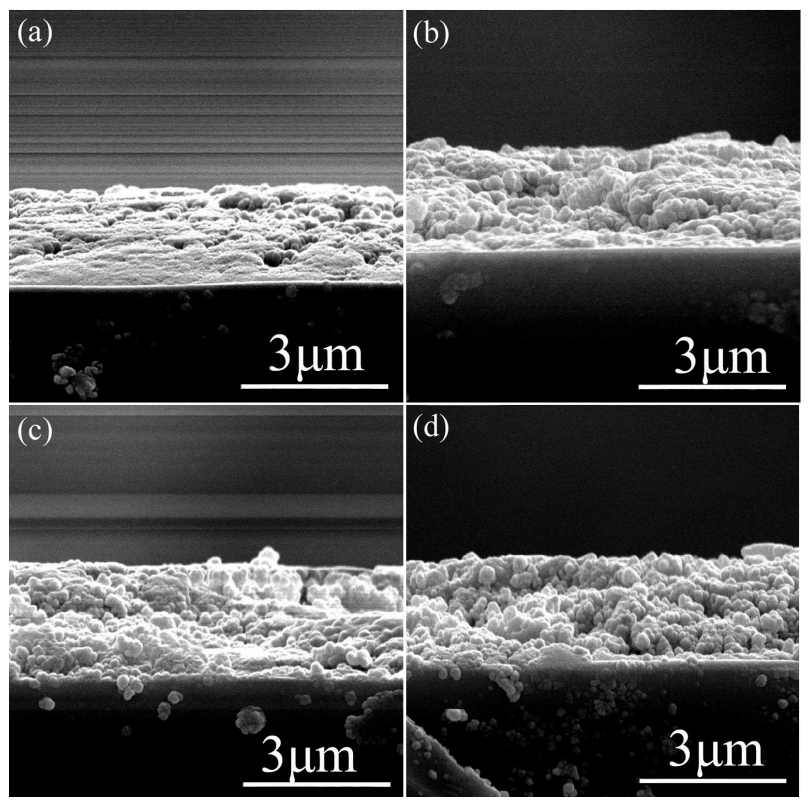

Fig. 9. Cross-section SEM images of amorphous $\mathrm{Cu}^{-}$ $\mathrm{Zn}-\mathrm{Sn}-\mathrm{S}$ precursor annealed with sulfur powder at different temperatures of (a) 360, (b) 400, (c) 440, and (d) $480^{\circ} \mathrm{C}$, respectively.

As $\mathrm{ZnS}, \mathrm{Cu}_{2} \mathrm{SnS}_{3}$, and $\mathrm{Cu}_{3} \mathrm{SnS}_{4}$ have similar structure to $\mathrm{Cu}_{2} \mathrm{ZnSnS}_{4}$, it is difficult to distinguish them from XRD. The Raman spectrum of amorphous $\mathrm{Cu}-\mathrm{Zn}-\mathrm{Sn}-\mathrm{S}$ precursor film annealed at $480^{\circ} \mathrm{C}$ with sulfur powder is shown in Fig. 8. The Raman peaks at $286 \mathrm{~cm}^{-1}, 334$ $\mathrm{cm}^{-1}$, and $368 \mathrm{~cm}^{-1}$ confirm the formation of CZTS phase and no other phases are observed.

Figure 9 shows the cross-section SEM images of the amorphous $\mathrm{Cu}-\mathrm{Zn}-\mathrm{Sn}-\mathrm{S}$ precursor films annealed at different temperatures with sulfur powder. The amount and volume of the particles increase with increasing temperature. The thin films all have good adhesion.

Figure 10 shows the $(\alpha h \nu)^{2}$ vs photon energy plots for amorphous $\mathrm{Cu}-\mathrm{Zn}-\mathrm{Sn}-\mathrm{S}$ precursor annealed at different temperatures with sulfur powder, where $\alpha$ and $h \nu$ are absorption coefficient and photon energy, respectively.

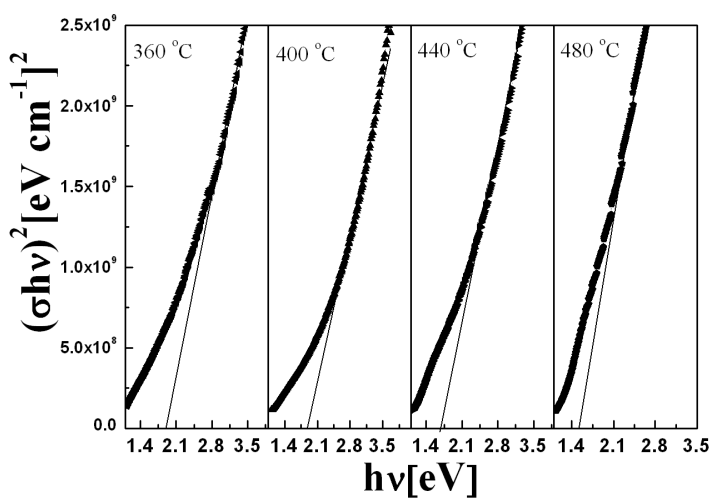

Fig. 10. The plots of $(\alpha h \nu)^{2}$ vs. photon energy for amorphous $\mathrm{Cu}-\mathrm{Zn}-\mathrm{Sn}-\mathrm{S}$ precursor annealed with sulfur powder at different temperatures of (a) 360, (b) 400, (c) 440 , and (d) $480{ }^{\circ} \mathrm{C}$, respectively.

The band gap values are estimated by extrapolating the straight line of $(\alpha h \nu)^{2}$ versus $h \nu$ plots to $h \nu$ axis. The band gaps of CZTS films annealed at 360, 400, 440, and $480^{\circ} \mathrm{C}$ are estimated to be $1.90,1.84,1.62$, and $1.50 \mathrm{eV}$, indicating that the band gap decreases with increasing temperature obviously. Combining results of Fig. 7, the bandgap decreases with increasing the $\mathrm{S}$ content. So, the change of the bandgap may be due to the change of the S content.

\section{Conclusions}

(1) Amorphous $\mathrm{Cu}-\mathrm{Zn}-\mathrm{Sn}-\mathrm{S}$ precursor films were prepared by sol-gel and spin-coating. A kesterite CZTS film with a small amount of $\mathrm{Cl}$ formed by annealing the precursor under Ar ambient at temperature above $200{ }^{\circ} \mathrm{C}$, but its atomic ratios of $\mathrm{Cu}: \mathrm{Zn}: \mathrm{Sn}: \mathrm{S}$ far deviated from stoichiometric ratios of the $\mathrm{Cu}_{2} \mathrm{ZnSnS}_{4}$.

(2) When the precursor films were annealed with $\mathrm{S}$ sulfur powder together at temperatures between 360 and $480^{\circ} \mathrm{C}$, the CZTS film with atomic ratio near the stoichiometric ratio and a very small amount of $\mathrm{Cl}$ formed. The $\mathrm{Cl}$ content decreases with increasing temperature, and a CZTS without $\mathrm{Cl}$ element is obtained when the temperature is $480^{\circ} \mathrm{C}$. The $\mathrm{Cl}$ may exist at the $\mathrm{S}$ site and is replaced by the $\mathrm{S}$ in annealing process.

(3) The band gap of the CZTS annealed with sulfur powder together decreases with increasing temperature, which may be attributed to substitution of $\mathrm{S}$ for $\mathrm{Cl}$.

\section{Acknowledgments}

This work is supported by the National Natural Science Foundation of China under Grant Nos. 10874178, 11074093, 61205038 and 11274135, Specialized Research Fund for the Doctoral Program of Higher Education under Grant No. 20130061130011, Ph.D. Programs Foundation of Ministry of Education of China under Grant No. 20120061120011, Natural Science Foundation of 
Jilin province under grant No. 201115013, and National Found for Fostering Talents of Basic Science under grant No. J1103202.

\section{References}

[1] H. Katagiri, Thin Solid Films 480-481, 426 (2005).

[2] H. Katagiri, K. Jimbo, S. Yamada, T. Kamimura, W.S. Maw, T. Fukano, T. Ito, T. Motohiro, Appl. Phys. Express 1, 041201-1 (2008).

[3] H. Araki, Y. Kubo, A. Mikaduki, K. Jimbo, W.S. Maw, H. Katagiri, M. Yamazaki, K. Oishi, A. Takeuchi, Sol. Energy Mater. Sol. Cells 93, 996 (2009).

[4] S.Y. Chen, X.G. Gong, A. Walsh, S.H. Wei, Appl. Phys. Lett. 94, 041903 (2009).

[5] A. Weber, H. Krauth, S. Perlt, B. Schubert, I. Kötschau, S. Schorr, H.W. Schock, Thin Solid Films 517, 2524 (2009).
[6] W. Shockley, H.J. Queisser, J. Appl. Phys. 32, 510 (1961).

[7] P.A. Fernandes, P.M.P. Salomé, A.F. da Cunha, J. Alloys Comp. 509, 7600 (2011).

[8] X.S. Yin, H. Gong, Acta Mater. 60, 6732(2012).

[9] K. Muska, M. Kauk, M. Altosaar, M. Pilvet, M. Grossberg, O. Volobujeva, Energy Procedia 10, 203 (2011).

[10] A.V. Moholkar, S.S. Shinde, A.R. Babar, K.U. Sim, H.K. Lee, K.Y. Rajpure, P.S. Patil, C.H. Bhosale, J.H. Kim, J. Alloys Comp. 509, 7439 (2011).

[11] J. He, L. Sun, K.Z. Zhang, W.J. Wang, J.C. Jiang, Y. Chen, P.X. Yang, J.H. Chu, Appl. Surf. Sci. 264, 133 (2013).

[12] M. Grossberg, J. Krustok, J. Raudoja, T. Raadik, Appl. Phys. Lett. 101, 102102-1 (2012). 
[13] A.V. Moholkar, S.S. Shinde, G.L. Agawane, S.H. Jo, K.Y. Rajpure, P.S. Patil, C.H. Bhosale, J.H. Kim, J. Alloys Comp. 544, 145 (2012).

[14] J.S. Wang, S. Li, J.J. Cai, B. Shen, Y.P. Ren, G.W. Qin, J. Alloys Comp. 552, 418 (2013).

[15] T. Tanaka, A. Yoshida, D. Saiki, K. Saito, Q.X. Guo, M. Nishio, T. Yamaguchi, Thin Solid Films 518, S29 (2010).

[16] N. Kamoun, H. Bouzouita, B. Rezig, Thin Solid Films 515, 5949 (2007).

[17] S.C. Riha, B.A. Parkinson, A.L. Prieto, J. Am. Chem. Soc. 131, 12054 (2009).

[18] M.L. Jiang, Y. Li, R. Dhakal, P. Thapaliya, M. Mastro, J.D. Caldwell, F. Kub, X.Z. Yan, J. Photon. Energy 1, 019501-1 (2011).

[19] H. Park, Y. H. Hwang, B.-S. Bae, J. Sol-Gel Sci. Technol. 65, 23 (2013).
[20] K. Tanaka, N. Moritake, M. Oonuki, H. Uchiki, Jpn. J. Appl. Phys. 47, 598 (2008).

[21] M. Y. Yeh, C. C.Lee, D. S. Wuu, J. Sol-Gel Sci. Technol. 52, 65 (2009).

[22] P.K. Sarswat, M.L. Free, Phys. Status Solidi A 208, 2861 (2011)

[23] B.S. Pawar, S.M. Pawar, K.V. Gurav, S.W. Shin, J.Y. Lee, S.S. Kolekar, J.H. Kim, ISRN Renewable Energy 2011, 1 (2011).

[24] A. Khalkar, K.S. Lim, S.M. Yu, S.P. Patole, J.B. Yoo, Int. J. Photoenergy 2013, 1 (2013).

[25] T. K.Chaudhuri, D. Tiwari, Solar En. Mater. Solar Cells 101, 46 (2012). 